\title{
Toprak ve Sucul Ortamlardaki Ağır Metal Kirliliği ve Ağır Metal Dirençli Mik- roorganizmalar
}

\author{
Orhan YAVUZ ${ }^{1 *}$, Nermin SARIGÜL ${ }^{2}$ \\ ${ }^{1}$ Mehmet Akif Ersoy Üniversitesi, Bilimsel ve Teknoloji Uygulama Araştırma Merkezi, Burdur \\ ${ }^{2}$ Mehmet Akif Ersoy Üniversitesi, Fen Edebiyat Fakültesi, Burdur \\ Geliş Tarihi (Received): 25.12.2015, Kabul Tarihi (Accepted): 11.02.2016 \\ $\square$ Sorumlu Yazar (Corresponding author)*: orhan.yavuz.23@gmail.com \\ (C) +902482133266 圆 +902482133288
}

ÖZ

Ağır metal kirliliği, gelişen sanayi faaliyetleri ile beraber günümüzün en önemli çevre sorunlarından biri haline gelmiştir. Ağır metal kirliliği özellikle sucul ortamlarda birikime neden olmaktadır. Sucul ortamlarda yaşayan ve bu sucul ortamlarla ilişkili tüm canlıların yaşam döngüsü ağır metal kirliliğinden olumsuz yönde etkilenmektedir. Canlılar geliştirdikleri ağır metal direnç sistemleri ile ağır metallerin toksik etkilerinden korunabilirler. Ağır metal direnç sistemleri mikroorganizmalarda yaygın olarak gözlenmektedir. Bu literatür çalışmasında ağır metaller ve ağır metal dirençli mikroorganizmaların direnç sistemleri anlatılmaktadır.

Anahtar Kelimeler: Sucul ortamlar, ağır metal direnç sistemleri, mikroorganizmalar

\section{Heavy Metal Pollution and Heavy Metal Resistant Microorganisms in the Soil and Aquatic Environments}

\begin{abstract}
Because of increasing industrial activity, heavy metal pollution is todays one of the most important environmental problem. Heavy metal pollution is causes an accumulation especially in aquatic environments. Heavy metal pollution is negative affect on the life cycle of the organisms that living in aquatic environment and related to aquatic environment. Organisms can prevent heavy metals toxic effect due to their heavy metal resistance systems. Heavy metal resistance system has been observed extensively in microorganisms. In this review, it has been explained heavy metals and heavy metal systems of heavy metal resistant microorganisms.
\end{abstract}

Keywords: Aquatic environments, heavy metal resistance systems, microorganisms

\section{Giriş}

Günümüz yaşamının ayrılmaz bir parçası olan sanayi ve madencilik faaliyetleri ağır metal kirliliğinin geldiği noktanın en büyük etkenlerinden birisi olarak görülmek- tedir. Ağır metaller yoğunluğu $5 \mathrm{~g} / \mathrm{cm}^{3}$ den yoğun olan ve canlılar üzerinde toksik etki gösteren metallerdir (Lars Järup, 2003). Periyodik tabloda var olan 90 element; 21 metal olmayan, 16 hafif metal ve 53 ağır metal olarak ayrımaktadır. Bakır, çinko, kobalt, arsenik, 
civa, kadmiyum, krom ve kurşun gibi metaller dahil olmak üzere 60'a yakın metal ağır metal olarak kabul edilmektedir (Kahvecioğlu ve ark., 2003). Ağır metaller insanlar tarafından yaklaşık 5000 yıldan bu yana farklı amaçlarla kullanılmaktadır. Metal ve ağır metallerin kullanımı ilk olarak yapı materyali, cam ve seramik yapımı ve taşıma boruları olarak başlamıştır. Fakat sanayi devrimiyle beraber bu metallerin kullanımı eskiye oranla ciddi bir artış göstererek yüksek miktarda ağır metalin doğal kaynaklara karışmasına neden olmuştur. Günümüzde devam etmekte olan farklı maden-sanayi faaliyetleri ve şehirsel atıklar çevreye ağır metal yayılımının devam etmesine neden olmaktadır.

Çevreye yayılan ağır metaller yüzeysel su akıntıları, yeraltı su kaynakları ve asit yağmurları ile deniz ve göller gibi sucul ortamlara taşınıp buralarda birikim gösterirler. Ağır metaller ilk olarak sedimentte birikir ve sedimentin adsorbsiyon kapasitesinin aşılmasıyla sularda birikime devam ederler. Bu yayılım az gelişmiş ülkelerde artmaya devam etmekte iken daha gelişmiş ülkelerde son yüzyıl içinde ağır metal yayılımında azalma gözlenmiştir. Bu metaller içerisinde özellikle kurşun, kadmiyum civa ve arsenik insanlar üzerinde olumsuz etki gösteren en önemli metallerdir (Lars Järup, 2003). Ağır metallere maruz kalmanın toksik zehirlenmeler, böbrek yetmezliği, akciğer problemleri, stres, uykusuzluk ve baş ağrısı gibi sinir sistemi rahatsızlıkları, karın ağrısı, gastrointestinal sistem rahatsızlıkları gibi sindirim sistemi rahatsızları, teratojeni ve uzun vadede mutasyonlar ve kansere sebep olduğu bilinmektedir. Ağır metaller insanlar için olduğu gibi diğer bitki, hayvan ve mikroorganizmalar üzerinde de olumsuz etkilere neden olmaktadır. Ağır metal kirliliği mikroorganizmaların hücre duvarı, nükleik asit, protein yapısı ve yaşamsal sistemleri üzerinde olumsuz etkilere neden olarak yaşam süreçlerini olumsuz yönde etkilemektedir. Ağır metal kirliliğine maruz kalan bölgelerde yaşayan mikroorganizmalar ölüm, biyoçeşitliliğin bozulması ve türün tamamen ortadan yok olması gibi tehditlerle karşı karşıyadır. Fakat ağır metal kirliliği karşısında bazı mikroorganizmalar geliştirdikleri farklı sistemler ile bu metallerin olumsuz etkilerinden korunmaktadır. Ağır metal direnç genleri kromozom ya da plazmidler üzerinde bulunabilir. Mikroorganizmalar ağır metallere karşı direnci temel hücre bileşenlerinde yaptıkları yapısal değişiklikler veya sentezledikleri yeni hücre bileşenleri ile sağlarlar. Yapılmış çalışmalarda ağır metal kirliliğine maruz kalmış ortamlarda dirençli farklı türlerin varlığı rapor edilmiştir (Filali ve ark., 2000; Li ve Ramakrishna, 2011; Roosa ve ark., 2014).

\section{AĞIR METAL KİRLİLí̆̇̇ KAYNAKLARI}

\section{Ağır Metallerin Kullanım Tarihçesi}

Ağır metaller tarihin başından bu yana farklı amaçlarla işlenmiş ve kullanılmıştır. Bu amaçların başında madencilik, demir-çelik sanayi, cam ve seramik sanayi, kağıt endüstrisi, petrokimya sanayi, enerji üretimi ve gübre üretimi gibi günümüzün önemli endüstriyel faaliyetleri gelmektedir. Bu endüstriyel faaliyetlerin kontrolsüz devamı ve bunun yanında imha edilmek yerine doğaya atılan şehirsel atıklar ağır metal kirliliğini hızla artan hale getirmiştir. Ağır metallerin toksik etkilerinin bilinmemesi nedeniyle eski çağlarda çok yaygın kullanılmıştır. Antik Roma da yıllanmış şarapların tatlandırılması için kurşun asetat kullanıımış ve bunun sonucunda ortalama bir Romalı günde en az 1 gram kurşun tüketmiştir. Yine Romalılar civayı yeni doğan ve çocuklarda diş ağrısı tedavisinde ve ilerleyen dönemlerde (MS 1300-1800) frengi tedavisinde kullanmışlardır. Claude Monet 1800 'lerin ortalarında yaptığı çalışmalarda sıkça kadmiyum pigmentleri kullanmaktaydı fakat 1900'lere kadar metalin az bulunur olması sanatçıları metaller ile çalışma konusunda sınırlamıştır. Uzun bir süredir metallerin çevre ve doğa üzerindeki olumsuz etkilerinin bilinmesine rağmen metallerin yayılımı bazı bölgelerde artış göstermeye devam etmektedir. Civanın Latin Amerika'nın birçok bölgesinde hala altın madenciliğinde kullanılması, arseniğin yaygın kullanılan bir kereste koruyucusu olması ve bunun yanında tetraetil kurşun'un hala petrol ürünlerinde katkı maddesi olarak kullanımı ağır metal kullanımı konusunda önemli örnekler arasında yer almaktadır. 19. yüzyılın ortalarından bu yana ağır metal kullanımı ve çevreye yayılımı artış göstermektedir. 20. Yüzyılın sonlarında ağır metallerin çevre tarafından emisyonunda gelişmiş ülkelerde düşüş gözlenmektedir. Ingiltere'de 1990 ve 2000 yılları arasında ağır metal emisyonu \% 50 den fazla azalma göstermiştir.

\section{Günümüzde Ağır Metallerin Kullanımı ve Çevreye Yayılımı}

Ağır metaller çevreye farklı kaynaklardan yayılırlar (Tablo 1). Kadmiyum, doğada maden olarak bakır, kurşun ve çinko ile beraber bulanan bir elementtir. Kadmiyum PVC ürünlerinin stabilizasyonu ,renk pigmenti, çeşitli alaşımların yapısında ve günümüzde yaygın olarak şarj edilebilir nikel-kadmiyum pillerde kullanılmaktadır. Metalik kadmiyum ise anti-korozyon ajanı olarak kullanılmaktadır (cadmiation). Kadmiyum kirliliğinin en önemli etkeni olarak fosfat gübreleri olarak kabul edilmektedir. Avrupa ülkelerinde fosfat gübrelerinin kullanımında 1990'lar boyunca yönetimler tarafından getirilen kısıtlamalarla azalma gözlenmiştir. Avrupa ülkelerindeki bu azalmaya rağmen dünya genelinde kadmi- 
yum kirlenmesinde ciddi bir artış gözlenmektedir. Kadmiyum içeren ürünler genelde geri dönüştürülebilir ürünler olmasına rağmen bu artış engellenememektedir. Bu artış ise etkisini toprak, su gibi alanlarda göstermekte ve tüketilen sebze ve meyvelerle insana geçmektedir.

Civa; ilk olarak bir civa bileşiği olan zincifre tarih öncesi dönemlerde mağara resimlerinde kırmızı renk maddesi olarak kullanılmıştır. Bunun yanında Antik Yunan da ise metalik civa cilt parlatıcı bir kozmetik olarak kullanılmıştır. Tıpta ilk olarak frengi tedavisinde kullanılmıştır ve günümüzde hala amalgam olarak bilinen civa bileşiği bazı ülkelerde diş dolgusu olarak kullanılmaya devam edilmektedir. Günümüzde metalik civa termometreler, barometreler ve kan basıncını ölçen cihazlarda kullanılmaktadır. Civaya en çok maruz kalan grup ise diş tedavisinden sorumlu personeldir. Civanın bu alanlarda kullanımı sonucu evsel ve tıbbi olarak doğaya yayılımı söz konusudur.

Kurşun; Eski dönemlerde kurşun yiyeceklerin pişirildiği ve saklandığı kaplarda kullanılırdı hatta yıllanmış şarapların tatlandırılmasına kadar kullanılırdı. Son yüzyılda çevremizdeki kurşun kirliliğinin \%50 sinden fazlasının temel sebebi petrol ürünleridir. Son 50 yıl da gelişmiş ülkelerde kurşunsuz benzin kullanımı ile kurşun salınımında ciddi bir azalma gözlenmektedir. İnorganik kurşun kirliliğinin kaynağı ise madencilik ve kazı faaliyetleridir. Diğerlerine göre daha düşük bir kurşun kirlilik etmeni ise metal kaynak çalışmaları ve cam sanayidir. Hava kaynaklı kurşun buradan toprak ve suya geçerek toprak ve sucul ortamlara da karışmaktadır.

Arsenik; Arsenik yaygın olarak metalloid, kayaların içi, hava, toprak ve su da bulunur. Birçok ülkede içme suyu olarak kullanılan yüzey suları inorganik arsenik içermektedir (Çin, Şili ve Bangladeş). Fakat organik arsenik (Örneğin; Arsenobetain) balıkların vücutlarında depo edilir ve bu balıkların tüketimiyle insana geçer. Demir olmayan metallerin dökümü ve fosil yakıtlardan enerji üretimi işlemleri hava, toprak ve sudaki arsenik kirliliğinin en önemli iki nedenidir. Döküm faaliyetleri ise insan kaynaklı kirliliğin en önemli sebebi olarak kabul edilmektedir. Diğer kirlilik kaynakları ise fabrikalar, arsenik içeren pestisitler ve kereste koruyucularıdır.
Tablo 1. Ağır metaller ve yayılımına sebep olan endüstriyel faaliyetler (Kahvecioğlu ve ark., 2003).

\begin{tabular}{|l|c|c|c|c|c|c|c|c|}
\hline \multirow{2}{*}{$\begin{array}{l}\text { Endüstriyel } \\
\text { Faaliyet } \\
\text { Alanı }\end{array}$} & \multicolumn{7}{|c|}{ Ağır Metaller } \\
\cline { 2 - 9 } & $\mathrm{Cd}$ & $\mathrm{Cr}$ & $\mathrm{Cu}$ & $\mathrm{Hg}$ & $\mathrm{Pb}$ & $\mathrm{Ni}$ & $\mathrm{Sn}$ & $\mathrm{Zn}$ \\
\hline $\begin{array}{l}\text { Kağıt Endüst- } \\
\text { risi }\end{array}$ & - & + & + & + & + & + & - & - \\
\hline $\begin{array}{l}\text { Petrokimya } \\
\text { Klor-Alkali }\end{array}$ & + & + & - & + & + & - & + & + \\
\hline $\begin{array}{l}\text { Uretimi } \\
\text { Gübre Sanayi }\end{array}$ & + & + & + & + & + & - & + & + \\
\hline $\begin{array}{l}\text { Demir-Çelik } \\
\text { Sanayi }\end{array}$ & + & + & + & + & + & + & + & + \\
\hline $\begin{array}{l}\text { Enerji Üretimi } \\
\text { (Termik) }\end{array}$ & + & + & + & + & + & + & + & + \\
\hline
\end{tabular}

\section{AĞIR METAL DİRENCI}

Mikroorganizmalar direnç sistemleri geliştirerek ağır metallerin yoğun olduğu ortamlarda yaşamaya adapte olmuşlardır. Mikroorganizmalar çoğunlukla plazmid kodlu spesifik sistemlerle ağır metallere direnç göstermektedirler. Ağır metal direnci ile ilgili araştırmalar 1970'li yılların başında birkaç mikroorganizmanın ağır metal direnci gösterdiğinin tespit edilmesiyle başlamıştır. Bu mikroorganizmalar genelde aerobik grupta yer alan Staphylococcus sp., Escherichia coli, Pseudomonas aeruginosa ve Bacillus sp. türleridir (Nakahara ve ark., 1977; Marques ve ark., 1979; Harnett ve Gyles, 1984; Schwarz ve Hobel, 1989; Belliveau ve ark. 1991; Wang ve Shen, 1995). İlk olarak rastlanan direnç civa ve organomerküriyellere karşıdır. Ağır metal direnç sistemlerinin prokaryotik yaşamın başlangıcından hemen sonra geliştiği ve neredeyse tüm bakterilerde bulunduğu rapor edilmiştir (Ji ve Silver, 1995). Ağır metal direnci gösterdiği rapor edilen bazı mikroorganizmalar Tablo 2 de belirtilmiştir. Ağır metal direnci genelde antibiyotik direnci ile ilişkilidir (Nakahara ve ark. 1977; Harnett ve Gyles, 1984; McEntee ve ark. 1986; Schwarz ve Hobel, 1989; Belliveau ve ark. 1991). Bazı durumlarda belirli antibiyotik ve ağır metal direnci aynı plazmid üzerinde bulunur (Nakahara ve ark. 1977). Bazı mikroorganizmalar adaptasyonun ötesinde ortamdaki ağır metal kirliliğine karşı ortamı temizleyici organizmalar olarak görev yapmaktadırlar. Bu sebepten dolayı ağır metal direnci ve ağır metal dirençli mikroorganizmalar çevre için çok önemlidir. Mikroorganizmaların bu metallere farklı kro- 
mozomal , transpozon, plazmid kodlu sistemler ile adapte olduğu gözlenmiştir (Bruins ve ark.,2000).

Tablo 2. Ağır metal dirençli tespit edilmiş bazı mikroorganizma türleri

\begin{tabular}{|c|c|c|c|}
\hline Mikroorganizma & $\begin{array}{l}\text { Direnç } \\
\text { Gösterdiği } \\
\text { Metaller }\end{array}$ & $\begin{array}{l}\text { İzole Edildi- } \\
\text { ği Yer }\end{array}$ & Araştırmacı \\
\hline $\begin{array}{l}\text { Pseudomonas } \\
\text { aureginosa }\end{array}$ & $\mathrm{Cu}, \mathrm{Hg}$ & Atık su & $\begin{array}{l}\text { Hassen ve } \\
\text { ark., } 1998\end{array}$ \\
\hline Bacillus sp. & As & Toprak & \multirow{5}{*}{$\begin{array}{c}\text { Cavalca ve } \\
\text { ark., } \\
2010\end{array}$} \\
\hline $\begin{array}{l}\text { Stenotrophomonas } \\
\text { meltophila }\end{array}$ & $\mathrm{Zn}$ & Toprak & \\
\hline $\begin{array}{l}\text { Methylobacterium } \\
\text { mesophilicum }\end{array}$ & $\mathrm{Cd}$ & Toprak & \\
\hline $\begin{array}{l}\text { Micrococcus lu- } \\
\text { teus }\end{array}$ & $\mathrm{Pb}$ & Toprak & \\
\hline $\begin{array}{l}\text { Voriovorax para- } \\
\text { doxus }\end{array}$ & $\mathrm{Ag}$ & $\begin{array}{l}\text { Gümüş ma- } \\
\text { deni yakınla- } \\
\text { rından }\end{array}$ & \\
\hline Bacillus arsenicus & $\begin{array}{l}\text { Co, Se, } \mathrm{Hg} \\
\text { As, Cu, } \\
\text { Zn, Mg, } \\
\text { Cd, Pb }\end{array}$ & Sediment & \multirow{3}{*}{$\begin{array}{l}\text { Nithya ve } \\
\text { ark., } \\
2011\end{array}$} \\
\hline $\begin{array}{l}\text { Planococcus mari- } \\
\text { timus }\end{array}$ & $\begin{array}{lr}\mathrm{Co}, & \mathrm{Se}, \\
\mathrm{Hg}, & \mathrm{As}, \\
\mathrm{Cu}, & \mathrm{Zn}, \\
\mathrm{Mg}, & \mathrm{Cd}, \mathrm{Pb}\end{array}$ & Sediment & \\
\hline $\begin{array}{l}\text { Staphylococcus } \\
\text { Pasteuri }\end{array}$ & $\begin{array}{lr}\mathrm{Co}, & \mathrm{Se}, \\
\mathrm{Hg}, & \mathrm{Mn}, \\
\mathrm{As}, & \mathrm{Cu}, \\
\mathrm{Mg}, & \mathrm{Cd}, \mathrm{Pb} \\
\end{array}$ & Sediment & \\
\hline Pseudomonos sp. & $\mathrm{Cu}$ & Nehir & \multirow{3}{*}{$\begin{array}{l}\text { Chihomvu } \\
\text { ve ark., } \\
2015\end{array}$} \\
\hline Lysinibacillus sp. & $\mathrm{Cu}$ & Nehir & \\
\hline Escherichia coli & $\mathrm{Cu}$ & Nehir & \\
\hline
\end{tabular}

Ağır metal direnç sistemleri genel olarak 6 sınıfa ayrılabilir. Bunlara aşağıdaki başıklar altında değinilmiştir.

\section{Metalin Hücre İçine Alınmasının Engellenmesi}

Hücre duvarı veya membranda yapılan yapısal değişikliklerle geçirgenliği azaltarak veya ekzopolisakkarit tabaka tarafından bu iyonları bağlayarak toksik metal iyonlarının hücre içine alınımının engellenmesiyle gerçekleşir. Bu sistemin en önemli örneği $E$. Coli B de membranda bulunan porin proteininde yapılan değişiklik ile metal iyonlarının hücre dışında tutulmasıdır (Rouch ve ark.,1995). Bu sistem genelde tek bir genin mutasyonu ile meydana gelir ve membranın metal iyonlarına karşı geçirgenliğini azaltır (Ji ve Silver, 1995). Bir diğer sistem ise metal iyonlarının hücre duvarı veya membran tarafından spesifik olmadan bağlanmasıdır. Bu şekilde metal bağlanma noktaları doygunluğa ula- şıncaya kadar korunma sağlanmaktadır (Beveridge ve Murray, 1976; Hoyle ve Beveridge, 1983). Bakterilerde ekstrasellülar tabakanın doğal olarak canlılığın devamı için gereken metal iyonlarını degrede etme ve saklama kapasitesi vardır (Scott ve ark. 1988; Scott ve Palmer, 1990). Kadmiyum iyonlarının hücre dışında tutulması genelde bu sistemle gerçekleşir. Klebsiella aerogenes de bulunan ekstrasellüler kapsül $1 \mathrm{nM}$ den büyük olan kadmiyum iyonlarının hücre içine alınmasını engeller (Mergeay, 1991). Pseudomonas sp. de bulunan bakır iyonlarının periplazmik bağlanması sisteminde ise direnci sağlayan operon copA, $\operatorname{copB}$, $c o p C$ ve $c o p D$ olmak üzere dört genden meydana gelir. Bunlardan copA ve copB kısmi bakır direnci sağlarken copC ve copD nin katılması ile tam bir bakır direnci şağlanmış olur (Silver ve Walderhaug, 1992; Silver ve Ji, 1994). Bu sistemler bize metal iyonlarının hücre içine girişini engellemek için oluşan konformasyonel değişiklikleri göstermektedir. Bu sistemler genelde düşük seviyede (0.01 $\mathrm{mM}$ ve $0.1 \mathrm{mM}$ ) kadmiyum direncinde karşımıza çıkmaktadır (McEntee ve ark. 1986).

\section{Metal İyonlarının Hücre Dışına Taşınması}

Aktif taşıma ya da efflux sistemler metal direnç sistemleri içinde en yaygın olan kategoridir. Mikroorganizmalar hücre içine girmiş olan toksik metal iyonlarını aktif taşıma yolu ile sitoplazma dışına taşır. Bu sistem kromozomal veya plazmid tarafından kodlanmış olabilir. $\mathrm{Bu}$ sistemde mikroorganizma için gerekli olmayan metal iyonları besin maddelerinde olduğu gibi hücre içine alınır fakat hızlı bir şekilde sitoplazma dışına taşınır (Silver ve Walderhaug, 1992). Bu sistemin en önemli örnekleri $E$. coli ve $S$. aureus da plazmid kodlu ars operonu tarafından As(V) ve As (III) direnci, S. aureus, Bacillus $s p$. ve Listeria $s p$. da cad operonu ve Alcaligenes eutrophus da bulunan $c z c$ operonu tarafından sağlanan kadmiyum direnci ve $E$. coli de bulunan ZntA operonu ve $S$. aureus da bulunan cadA direnç sistemleridir (Silver ve Walderhaug, 1992; Nies,1992; Ji ve Silver, 1995; Rensing ve ark. 1998).

\section{Metallerin Hücre İçi Biriktirilmesi}

Mikroorganizma sitoplazmasına giren ağır metallerin sitoplazma içerisinde biriktirilerek hücre bileşenlerini toksik etkilerden korumaya yönelik bir sistemdir. Hücre içerisinde biriktirilen metaller genelde kadmiyum, bakır ve çinkodur. Bu sistemin iki önemli örneği öne çıkmaktadır; Synechococcus sp.'de metalothionin üretimi ve Pseudomonas sp.'de sisteince zengin proteinlerdir (Rouch ve ark. 1995; Silver ve Phung, 1996). Synechococcus sp. deki direnç sistemi smtA ve smtB olmak üzere iki genden oluşur. SmtA kadmiyum, bakır ve çinko bağlayan metallothionin proteinin üretiminden sorumludur (Silver ve ark. 1989; Silver, 1992). Bu gen 
yüksek düzeyde kadmiyum, bakır ve çinko varlığında indüklenir ve $s m t B$ üretimini baskılar. $S m t B$ baskılandığı zaman smtA gibi davranıp metalothionin üretimini sağlar (Silver ve ark., 1989). Bugüne kadar sadece Synechococcus sp. ve Cyanobacteria suşları metallothionin üretimi göstermiştir (Silver ve ark.1989). Bu tip sisteince zengin metallothionin üretimi hayvanlardan sonra ilk defa bu türlerde görülmüştür (Silver ve ark.1989). Hücre içi birikim gösteren diğer organizma ise kanalizasyondan izole edile Pseudomonas putida türüdür. Bu mikroorganizma metalothionin' e benzer üç farklı düşük moleküler ağırlıklı sisteince zengin protein üretimi vardir (Trevors ve ark. 1986). Mycobacterium scrofulaceum da ise bakır iyonlarının siyah bakır çökeltileri şeklinde biriktirildiği gözlenmiştir (Mergeay, 1991).

\section{Metallerin Hücre Dışında Biriktirilmesi}

Metal iyonlarının hücre dışı birikimi bazı küf ve mayalarda görülen bir ağır metal direnç sistemidir (Joho ve ark., 1995). Ni (II) direncinin mayalarda görülen bir tipinin bu sistem temelli olduğu düşünülmektedir. Saccharomyces cerevisiae $\mathrm{Ni}$ adsorbsiyonunu glutatyon yardımıyla düşürmektedir. Glutatyon ağır metallere karşı yüksek afinite göstermektedir. Metal zengin ortamlarda bulunan mayaların hücre dışı metal bağlayan glutatyon dan sorumlu methylglyoxal direnç genini taşıdığı gözlenmiştir (Murata ,K. 1985). Direnç sonucu metaller hücre dışında bağlanarak hücre içine giremezler. Benzer bir mekanizma yine mantarlardaki Cu (II) direncinde gözlenmiştir (Murphy ve Levy, 1983). Bu mantarlar ağır metaller ile kompleks oluşturan oxalate salgılamaktadırlar. Maya ve Citrobacter sp. gibi diğer bazı organizmalar ise kadmiyum fosfat gibi çözünmez kompleksler ile ağır metallere direnç sağlanmaktadırlar (McEntee ve ark., 1986). Mayaların bu direnç için sülfit üretimini kullandığı gözlenirken Citrobacter $s p$. de ise fosfat kullanıldığı görülmüştür (Nies, 1999). Klebsiella aerogenes S45 suşu çevresindeki $\mathrm{Cd}$ (II) iyonlarını salgıladığı sülfit ile presipite ederek kendi etrafında taşımaktadır. Bu taşıma presipitat oluşumu doygunluğa ulaşana kadar devam etmektedir (Aiking ve ark., 1982).

\section{Enzimatik Detoksifikasyon}

Civa direnci enzimatik detoksifikasyonun mikroorganizmalardaki model örneğidir. Bu direnç sisteminden daha iyi bilinen bir direnç sistemi henüz bulunmamaktadır. Hem gram pozitif ( $S$. aureus, Bacillus $s p$.) hem de gram negatif (Escherichia coli, Pseudomonas aeruginosa, Serratia marcescens ve Thiobacillus ferrooxidans) mikroorganizmalarda civa direnci gözlenmiştir (Misra, 1992). Civa hücre içine girdiği zaman thiol gruplarına bağlanarak proteinleri ve enzimleri inaktive ederek toksik etki gösteren bir metaldir. Bazı bakteriler civa direncinden sorumlu bir grup geni içeren civa direnç operonuna (mer) sahiptir. Bu operon sadece civa detoksifikasyonu yapmaz bunun yanında civanın taşınması ve hücrenin civaya direncini de düzenler (Misra, 1992; Ji ve Silver,1995). Direnç genleri hem hücre dışı bağlanma proteinlerini hem de membrandan taşınması için gerekli proteinlerin sentezlenmesini sağlar. Periplazmik bağlayıcı proteinler hücrenin etrafındaki civayı bağlar ve bu civa molekülleri membrandan taşıma proteinleri ile hücre içine taşınarak detoksifiye edilirler.

Civa direnç genleri, organomerkuriyal liyaz ve civa iyon redüktaz olarak iki önemli enzimi kodlarlar. Mikroorganizmaları sahip oldukları civa direnç genleri ve enzimlerine göre geniş ve dar spektrumlu olmak üzere iki ana gruba ayırabiliriz. Dar spektrumlu olanlar sadece sınırlı sayıda organomerküriyal liyaz genlerini içermektedir, bu nedenle az sayıda organomerküriyal bileşiğe karşı direnç gösterirler. Geniş spektrumlu civa direncine sahip olan mikroorganizmalar ise her iki enzimi de kodlayan genlere sahip olduğu için çok sayıda organomerküriyel bileşiğe direnç gösterirler (Weiss ve ark., 1997; Misra, 1992).

mer operonu bazı mikroorganizmaların plazmidlerinde çalışılmış ve yaygın olarak 5 veya 6 gen içerdiği gözlenmiştir (Misra, 1992). Bu genler; merA (civa redüktaz) , merB (organomercurial redüktaz enzimini), merC (taşıma proteinini), merD (mer genlerinin ekspresyonunu düzenleyici), merR (aktivatör proteini), merP (taşıma proteini) ve merT (taşıma proteini) dir. mer genleri Shigella flexneri de transpozon Tn21, S. marcescens de plazmid pDU 1358 ve $P$. aeruginosa da transpozon Tn501 de olduğu gibi farklı bakterilerde farklı bölgelerde kodlanmıştır. Fakat farklı mikroorganizmaların mer operonlarının gen ve fonksiyonel yapıları arasındaki benzerlik \%80' in üzerinde bulunmuştur (Misra, 1992).

\section{Hücre Hassasiyetinin Düşürülmesi}

Bazı mikroorganizmalar yoğun ağır metal içeren ortamlarda temel hücre bileşenlerinde değişikliğe giderek doğal bir koruma sağlarlar (Rouch ve ark., 1995). Bu değişiklikler mutasyonlarla gerçekleşmektedir, hücre bileşenlerinin duyarlılığı düşürülürken temel işlevlerinde değişiklik olmamaktadır. DNA tamir mekanizmaları genomik DNA ve plazmidlerin tamiri ve korunmasını sağlar. Mikroorganizmalar ağır metallerden korunmak için genelde metal dirençli bileşenler sentezlerler ya da hassas hücre bileşenlerinin en az zarar göreceği metabolizma yolları geliştirirler. Bu adaptasyon E. coli de gözlenmiştir. Kadmiyuma maruz kalan ve adapte olamamış bir $E$. coli de yüksek derecede DNA hasarı gözlenir fakat daha sonra $E$. coli tekrar kadmiyuma maruz bırakılarak kültüre edildiği zaman kadmiyuma karşı bir direnç gösterdiği gözlemlenmiştir (Mergeay, 1991). 
Mikroorganizmaların doğal yapıları ve fonksiyonları onlara belirli düzeyde bir tolerans ve direnç kazandırmaktadır (Rouch ve ark., 1995). Örnek olarak glutatyon $\mathrm{Ag}(\mathrm{I}), \mathrm{Cu}(\mathrm{I}, \mathrm{II}), \mathrm{Cd}(\mathrm{II}), \mathrm{Hg}(\mathrm{II}), \mathrm{Cu}(\mathrm{II})$ ve $\mathrm{Fe}(\mathrm{II})$ gibi bazI metallere karşı koruma sağlamaktadır (Ni'bhriain ve ark. 1983; Rouch ve ark. 1995). Gram negatif ve Gram pozitif mikroorganizmaların bazı metal iyonlarına tolerans gösterme kabiliyeti arasında farklılıklar vardır (Morozzi ve ark. 1986). Gram negatif bakteriler Gram pozitif bakterilere göre Cd (II) varlığında protein sentezini daha iyi sürdürebilmektedirler. Diğer taraftan Gram pozitif mikroorganizmalar E. coli ile karşılaştırıldığında $28-30$ kat daha fazla $\mathrm{Cu}(\mathrm{II})$ bağlayabilirler (Beveridge ve Fyfe, 1985).

\section{AĞIR METAL DIRENCININ TESPIT EDILMESi}

Mikroorganizmalarda ağır metal direnci tespitinde kültürel yöntemler, genom sekansı, polimeraz zincir reaksiyonu (PZR), DNA probları, protein elektroforezi ve Western blotlama gibi yöntemler kullanılmaktadır. Kültürel yöntemler daha çok ağır metal tuzlarını içeren ortamlarla mikroorganizma izolasyonu ve farklı metallerle büyüme koşullarının gözlemlenmesi amacı ile kullanımaktadır. Bu çalışmalarda her bir ağır metal ayrı ayrı ortamlara karıştırılarak test edilebildiği gibi birden çok metali aynı anda ortama ilave ederek çoklu direnç denemeleride yapılabilir. Katı veya sıvı besi ortamları çaıışmalarda kullanılabilmektedir. Ağır metal direncinin belirlenmesinin yanında Minimum İnhibisyon Konsantrasyonunu (MiK) belirlenmesi de gerekmektedir. MiK tayini farklı oranlarda ağır metal içeren katı veya sıvı besiyerileri kullanılarak yapılabilir (Hassen ve ark., 1998).

Ağır metal direncini tespit etmek için kullanılan bir diğer yöntem ise ise moleküler yöntemlerdir. Moleküler yöntemlerde yaygın olarak PZR ile ağır metal direnç genlerinin varlığının taranması kullanılır. Bunun yanında genom sekansı, DNA probları, poliakrilamid jel elektroforezi ve Western blotlama gibi yöntemleride kullanılmaktadır. PZR metoduna bakacak olursak ağır metal direnci sağlayan genlere spesifik primerlerin seçilmesi ve PZR ile çoğaltılıp görüntülenmesi şeklinde ilerler. Kültürel ve moleküler yöntemlerin aynı anda yürütülmesi ile direnç varlığı, derecesi ve bu dirençten sorumlu genin ifade edilmesi şeklinde sonuçlar elde edilebilmektedir. Yapılmış çalışmalarda ağır metal kirliliğine maruz kalmış sucul ortamlar ve sedimentleri ve atık sulardan izole edilen mikroorganizmaların krom, kobalt, çinko, kadmiyum, kurşun, civa, bakır, arsenik, magnezyum, mangan ve selenyum gibi metallere karşı dirençliliği tespit edilmiştir. Escherichia coli, Bacillus thuringiensis, Streptococcus sp., Staphylococcus aureus, Pseudomonas aeruginosa, Pseudomonas paucimobilis, Pseudomonas cepacia, Providencia rettgeri, Proteus mirabi- lis, Aeromonas hydrophila, Acinetobacter calcoaceticus, Citrobacter freundii, Klebsiella rhinoscleromatis, Bacillus arsenicus, B. pumilis, B. indicus, B. clausii, Planacoccus maritimus, Staphylococcus pasteuri, Pseudomonas fluorescens, Pseudomonas aeruginosa, Klebsiella pneumoniae, Proteus mirabilis ve Staphylococcus sp. gibi Gram negatif ve pozitif birçok türde ağır metal direnci tespit edilmiştir (Hassen ve ark.,1998, Filali ve ark., 2000, Nithya ve ark., 2011). Minimum inhibisyon konsantrasyonunun ise $0,02-400 \mathrm{mM} / \mathrm{L}$ arasında olduğu gözlenmiştir (Hassen ve ark., 1998, Li ve Ramakrishna, 2011). Çalışılan mikroorganizmalarda aynı anda birden çok ağır metal karşı direnç olduğu tespit edilmiştir (Filali ve ark., 2000). Ağır metal direncinin belirlenmesinde çeşitli gen bölgelerinin varlığı ya da yokluğunun tespitinden de yararlanılmaktadır. Arsenik direncinin belirlenmesinde; $\operatorname{ars} \mathrm{A}$, $\operatorname{ars} \mathrm{B}$, ars $\mathrm{C}$, $\operatorname{ars} \mathrm{D}$, arsR, bakır için; copA, copB, copY, copZ pcoA kurşun için; pbrT, kadmiyum için; cadA, cadB, cadC korm için; chrA, chrB, civa için; merA, merB, merC, merD, merR, merP, merT kobalt-çinko-kadmiyum çoklu direnci için; $c z c \mathrm{~A}, c z c \mathrm{~B}, \quad c z c \mathrm{C}, c z c \mathrm{D}$, nikel-kobalt-kadmiyum çoklu direnci için; nccA gen bölgeleri bunlara uygun primerler kullanılarak çoğaltılmış ve görüntülenmiştir (Roosa ve ark., 2014; Abou-Shanab ve ark., 2007; Rouch ve ark., 1995; Bruins ve ark., 2000). Ağır metal direncinden sorumlu bazı gen bölgeleri NCBI gen bankasından araştırılarak Tablo 3'de verilmiştir.

Tablo 3. Ağır metal direncinden sorumlu bazı genler (http://www.ncbi.nlm.nih.gov/)

\begin{tabular}{|c|c|c|}
\hline Ağır Metal & $\begin{array}{ll}\text { Direnci } & \text { Kodlayan } \\
\text { Gen } & \end{array}$ & Bulunduğu Konum \\
\hline Bakır & $\begin{array}{l}\text { copA, } \quad \text { copB, } \quad \text { } \quad \text { copC, } \\
\text { copD }\end{array}$ & $\begin{array}{ll}\text { Kromozomal veya } \\
\text { Plazmid }\end{array}$ \\
\hline Kurşun & $p b r A, p b r D, p b r T$ & Plazmid \\
\hline Kadmiyum & $\operatorname{cadD}, \operatorname{cadX}$ & Plazmid \\
\hline Çinko & $c z r A, c z r B, c z r C$ & $\mathrm{NC}$ \\
\hline Civa & $\begin{array}{l}\text { merA, merB, merC, } \\
\text { merD, merE, merR }\end{array}$ & NC, Plazmid \\
\hline Arsenik & $\operatorname{ars\mathrm {D},}$ arsR & Plazmid \\
\hline $\begin{array}{l}\text { Kobalt-Çinko- } \\
\text { Kadmiyum }\end{array}$ & $c z c \mathrm{~A}, c z c \mathrm{~B}, c z c \mathrm{C}$ & Kromozom NC \\
\hline Nikel-Kobalt & cnrA, rcnA, cnrT & Plazmid NC \\
\hline
\end{tabular}

\section{SONUÇLAR}

Bakterilerdeki ağır metal dirençliliği, mikrobiyologların uzun süredir ilgisini çekmektedir. Ağır metaller çevreye endüstriyel ve zirai uygulamalar sonucu yayılmaktadır ve sucul ve karasal sistemlerde birikmektedir. Ağır metallerce kirletilmiş çevrelerden izole edilen bakteriler ağır metallerin toksik etkilerine karşı çeşitli mekanizma- 
lar kullanarak direnç kazanmışlardır. Karasal ve sucul çevrelerden ağır metallerin uzaklaştııılmasında biyolojik metotlar oldukça etkilidir. Biyolojik kütle içerisinde kompleks formda bulunan ağır metaller biyomadencilik, biyoremediasyon ve atık su arıtım tesislerinde farklı şekillerde değerlendirilmektedir.

Ağır metal dirençliliğini kodlayan genler aynı zamanda antibiyotik dirençliliğinde de etkilidir. Bu nedenle bu mikroorganizmalar sadece biyoremediasyon, biyomadencilik gibi uygulamalar için değil sağlık sektöründe de önem kazanmaktadır. Antibiyotiklerin keşfinden önceki dönemlerde yüzyıllarca ağır metaller hastalıkların tedavisinde ilaç olarak kullanılmıştır. Bu nedenle patojen mikroorganizmalarda da ağır metal dirençliliği gelişmiştir. Özellikle plasmid transferi ile bu plasmidler üzerinde bulunan direnç genleri tür içi ve türler arasında taşınabilir ve patojenitenin artmasına neden olabilir.

Ağır metal dirençliliği mekanizmalarının tam olarak anlaşılması ile kirletilmiş çevrelerin etkin olarak temizlenmesi, çevre dostu teknolojiler kullanılarak düşük cevher içerikli madenlerden yüksek kalitede ürün elde edilmesi ve patojen mikroorganizmalara karşı etkin yeni ilaçlar geliştirilmesi sağlanabilir.

\section{KAYNAKLAR}

Abou-Shanab, R. A. I., Van Berkum, P., Angle, J. S. (2007). Heavy metal resistance and genotypic analysis of metal resistance genes in gram-positive and gram-negative bacteria present in Ni-rich serpentine soil and in the rhizosphere of Alyssum murale. Chemosphere, 68(2): 360-367.

Aiking, H., Kok, K., Heerikhuizen, H. V., Van't, R. J. (1982). Adaption to cadmium by Klebsiella aerogenes growing in continous culture proceeds mainly via formation of cadmium sulfide. Appl. Environ. Microbiol. 44, 938-944.

Belliveau, B. H., Staradub, M. E., Trevor, J. T. (1991). Occurrence of antibiotic and metal resistance and plasmids in Bacillus strains isolated from marine sediment. Can. J. Microbiol. 37(5): 513-520.

Beveridge, T. J., Fyfe, W. S. (1985). Metal "xation by bacterial cell walls. Can. J. Earth Sci. 22, 1893-1898.

Beveridge, T. J., Murray, G. E. (1976). Uptake and retention of metals by cell walls of Bacillus subtilis. J. Bacteriol. 127, 1502-1518.

Bruins, M. R., Kapil, S., Oehme, F. W. (2000). Microbial resistance to metals in the environment. Ecotoxicology and environmental safety, 45(3): 198-207.

Chihomvu, P., Stegmann, P., \& Pillay, M. (2015). Characterization and Structure Prediction of Partial Length Protein Sequences of pcoA, pcoR and chrB Genes from Heavy Metal Resistant Bacteria from the Klip River, South Africa. International Journal of Molecular Sciences, 16(4): $7352-7374$.

Filali, B. K., Taoufik, J., Zeroual, Y., Dzairi, F. Z., Talbi, M., Blaghen, M. (2000). Waste water bacterial isolates resistant to heavy metals and antibiotics. Current microbiology, 41(3): 151-156.
Harnett, N. M., Gyles, C. L. (1984). Resistance to drugs and heavy metals, colicin production, and biochemical characteristics of selected bovine and porcine Escherichia coli strains. Appl. Environ. Microbiol. 48, 930-945.

Hassen, A., Saidi, N., Cherif, M., Boudabous, A. (1998). Resistance of environmental bacteria to heavy metals. Bioresource Technology, 64(1): 7-15.

Hoyle, B., Beveridge, T. S. (1983). Binding of metallic ions to the outer membrane of Escherichia coli. Appl. Environ. Microbiol. 46, 749\}752.

http://www.ncbi.nlm.nih.gov/ (Erişim Tarihi: 03. 12. 2015)

Ji, G., Silver, S. (1995). Bacterial resistance mechanism for heavy metals of environmental concern, J.Ind.Microbiol $14,61-75$

Joho, M., Inouhe, M., Tohoyama, H., Murayama, T. (1995). Nickel resistance in yeast and other fungi. J. Ind. Microbiol. 14, 164-168.

Kahvecioglu, Ö., Kartal, G., Güven, A., Timur, S. (2003). Metallerin çevresel etkileri-1, Metaluriji Dergisi, 136, 47-53

Lars Järup (2003), Hazards of metal contamination, British medical bulletin, vol 68:167-182.

Li, K., Ramakrishna, W. (2011). Effect of multiple metal resistant bacteria from contaminated lake sediments on metal accumulation and plant growth, Journal of Hazardous Materials 189, 531-539

Marques, A. M., Congregado, F., Simon-Pajol, D. M. (1979). Antibiotic and heavy metal resistance of Pseudomonas aeruginosa isolated form soils. J. Appl. Bacteriol. 47, 347350.

McEntee, J. D., Woodrow, J. R., Quirk, A. V. (1986). Investigation of cadmium resistance in an Alcaligenes sp. Applied and environmental microbiology, 51(3): 515520.

Mergeay, M. (1991). Towards an understanding of the genetics of bacterial metal resistance. Trends Biotechnol. 9, 17-24.

Misra, T.K. (1992), Bacterial resistance to inorganic mercury salts and organomercurials, Plasmid 27, 4-16.

Morozzi, G., Ceni, G., Scardazza, F., Pitzurra, M. (1986). Cadmium uptake by growing of gram-positive and gramnegative bacteria. Microbios. 48, 27-35.

Murata, K.(1985). Phenotypic character of the methylglycoxal resistance gene in saccharomyces cerevisae : expression in Escherichia coli and application to breeding wildtype yeast strains, App.Environment Microbiol, 50, 12001207

Murphy, R. J., Levy, J. F. (1983). Production of copper oxalate by some copper tolerant fungi. Br. Mycol. Soc. 81, 165168.

Nakahara, H., Ishikawa, T., Yasunaga, S., Kondo, I., Kozukue, H., Silver, S. (1977). Linkage of mercury, cadmium, and arsenate and drug resistance in clinical isolates of Pseudomonas aeruginosa. Appl. Environ. Microbiol. 33, 975-976.

Ni'bhriain, N. N., Silver, S., Foster, T. J. (1983). Tn5 insertion mutation in the mercuric ion resistance genes derived from plasmid R100-1. J. Bacteriol. 155, 690-703.

Nies, D. H. (1992). Resistance to cadmium, cobalt, zinc, and nickel in microbes., Plasmid 27, 17-28.

Nies, D. H. (1999). Microbial heavy-metal resistance. Applied microbiology and biotechnology, 51(6): 730-750.

Nithya, C., Gnanalakshmi, B., Karutha Pandian, S.K. (2011). Assessment and charecterization of heavy metal resis- 
tance in palk bay sediment bacteria, Marine environmental research 71, 283-294

Rensing, C., Sun, Y., Mitra, B., Rosen, B. P. (1998). Pb(II) translocating p-type ATPases. J. Biol. Chem. 273, 3261432617.

Roosa, S., Wattiez, R., Prygiel, E., Lesven, L., Billon, G., Gillan, D. C. (2014). Bacterial metal resistance genes and metal bioavailability in contaminated sediments. Environmental Pollution, 189, 143-151.

Rouch, D. A., Lee, B. T. D., Morby, A. P. (1995). Understanding cellular responses to toxic agents: A model for mechanism choice in bacterial metal resistance. J. Ind. Microbiol. 14, 132-141.

Schwarz, S. T., Hobel, H. (1989). Plasmid and resistance to antimicrobial agents and heavy metals in Staphylococcus hyicus from pigs and cattle. J. <et. Med. 36, 669-673.

Scott, J. A., Palmer, S. J. (1990). Sites of cadmium uptake in bacteria used for biosorption. Appl. Environ. Microbiol. 33, 221-225.

Scott, J. A., Sage, G. K., Palmer, S. J. (1988). Metal immobilization by microbial capsular coatings. Biorecovery 1,51 58.
Silver, S. (1992). Plasmid-determined metal resistance mechanisms: Range and overview. Plasmid 27, 1-3.

Silver, S., Ji, G. (1994). Newer systems for bacterial resistance's to toxic heavy metals. Environ. Health Perspect. 102, 107-113.

Silver, S., Nucifors, G., Chu, L., Misra, T. K. (1989). Bacterial resistance ATPases: Primary pumps for exporting toxic cations and anions. Trends Biochem. Sci. 14, 76-80.

Silver, S., Phung, L. T. (1996). Bacterial heavy metal resistance: new surprises. Annu. Rev. Microbiol. 50, 753-789.

Silver, S., Walderhaug, M. (1992), Gene regulation and choromosome-determined inorganic ion transport in bacteria, Microbiol Rev. 56:195-228

Trevors, J. T., Stratton, G. W., Gadd, G. M. (1986). Cadmium transport, resistance, and toxicity in bacteria, algae, and fungi. Can. J. Microbiol. 32, 447-464.

Wang, Y. T., Shen, H. (1995). Bacterial reduction of hexavalent chromium. J. Ind. Microbiol. 14, 159-163.

Weiss, A., Murphy, S., Silver, S. (1977). Mercury and organomercurial resistance determined by plasmids in Staphylococcus aureus. J. Bacteriol. 132, 197-208. 